\title{
Jurist-Diction
}

Volume 4 No. 2, Maret 202

\section{Tinjauan Yuridis Penerapan Prinsip Tanggung Jawab Komando di Indonesia sebagai Perwujudan Keadilan Transisi}

\author{
Adelwin Airel Anwar dan Harish Makarim \\ adelwin.anwar@gmail.com \\ Universitas Indonesia
}

How to cite:

Adelwin Airel Anwar dan Harish Makarim 'Tinjauan Yuridis Penerapan Prinsip Tanggung Jawab Komando di Indonesia sebagai Perwujudan Keadilan Transisi' (2021) Vol. 4 No. 2 Jurist-Diction.

Histori artikel:

Submit 4 Januari 2021;

Diterima 18 Februari 2021;

Diterbitkan 1 Maret 2021.

DOI:

10.20473/jd.v4i2.25746

p-ISSN: 2721-8392

e-ISSN: $2655-8297$

\section{Abstract}

The application of transitional justice is necessary to fulfill victims' rights who have been taken away due to gross human rights violations. That it is necessary to take responsibility for those who committed these crimes to bring about the elimination of impunity. Command responsibility is one way that the command who can control their subordinates can be held accountable. Unfortunately, the application of this doctrine in Indonesian law is considered unsatisfactory. The misapplication of this doctrine occurred in the case of gross human rights violations in Tanjung Priok because the facultative formulation of Article 42 of Human Rights Court Law failed to prosecute the commander on site. By using the juridical-normative method and literature study, this research aims to encourage the government to reform regulations related to human rights, especially on Command Responsibility. This research is a reflection to remember past-history of gross human rights violations in Indonesia.

Keywords: Command Responsibility; Transitional Justice; Gross Human Rights Violations; Impunity.

\begin{abstract}
Abstrak
Penerapan doktrin keadilan transisi diperlukan demi pemenuhan hak-hak korban yang terenggut karena terjadinya pelanggaran HAM berat. Sehingga perlu adanya pertanggungjawaban orang-orang yang melakukan kejahatan tersebut untuk mewujudkan terhapusnya impunitas. Tanggung Jawab komando merupakan salah satu cara agar komando dan atasan yang seharusnya memegang kendali terhadap anak buahnya dapat bertanggung jawab. Sayangnya, penerapan doktrin tersebut dalam hukum Indonesia dianggap kurang memuaskan. Kesalahan pengaplikasian doktrin tersebut terjadi di dalam kasus pelanggaran HAM berat di Tanjung Priok karena rumusan Pasal 42 dalam Undang-Undang Pengadilan HAM yang fakultatif sehingga gagal menjerat komandan yang ada di tempat. Dengan menggunakan metode yuridis-normatif dengan studi kepustakaan, penelitian ini bertujuan untuk mendorong pemerintah untuk membenahi peraturanperaturan terkait Hak Asasi Manusia khususnya dalam penerapan Tanggung Jawab Komando. Selain itu, penelitian ini disusun sebagai bentuk refleksi untuk mengingat kejadian masa lalu Pelanggaran HAM berat di Indonesia.

Kata Kunci: Tanggung Jawab Komando; Keadilan Transisional; Pelanggaran HAM Berat; Impunitas.
\end{abstract}

Copyright $(92021$ Universitas Airlangga 


\section{Pendahuluan}

Runtuhnya rezim Orde Baru yang ditandai dengan turunnya Soeharto dari kursi Presiden Republik Indonesia memberikan harapan baru bagi kehidupan sosial politik Indonesia ke arah yang lebih demokratis. Segera setelah itu B.J. Habibie yang sebelumnya merupakan wakil presiden dari Soeharto segera membentuk "Kabinet Reformasi Pembangunan" sebagai reaksi positif terhadap gerakan rakyat yang membawa gagasan reformasi untuk mencapai tujuan dalam mengoreksi kesalahankesalahan rezim orde baru di masa lalu dengan melakukan perlindungan Hak Asasi Manusia (HAM) seperti dengan cara membuat kebijakan berperspektif HAM, dan meratifikasi instrumen-instrumen internasional HAM. ${ }^{1}$ Namun, kuatnya tarik menarik di antara pendukung status quo Orde Baru dan para pengusung reformasi menyebabkan politik hukum dan HAM pada awal era reformasi memperlihatkan karakter politik hukum dan HAM yang kompromistik sehingga penyelesaian dan perlindungan mengenai HAM tidak terlalu memuaskan. Hal tersebut terlihat dalam kandungan peraturan perundang-undangan; baik yang terdapat dalam UUD 1945 perubahan ke-II, khususnya pasal yang mengatur HAM; UU No. 39 Tahun 1999 tentang Hak Asasi Manusia, serta UU No. 26 Tahun 2000 tentang Pengadilan Hak Asasi Manusia. ${ }^{2}$

Politik Hukum dan HAM yang terjadi di awal era reformasi menandakan sebuah adanya transisi dari suatu pemerintahan yang otoriter, ke suatu sistem kenegaraan yang menerapkan prinsip-prinsip demokrasi. Contoh yang bisa dilihat dalam peralihan tersebut adalah dengan diadakannya penyelesaian kasus pelanggaran HAM melalui non pengadilan biasa dilakukan dalam kondisi pemerintahan transisional. Tuntutan pemenuhan keadilan bagi korban pelanggaran HAM masa lalu yang ingin dicapai dalam suatu peralihan pemerintahan biasa diistilahkan dengan transitional justice (keadilan transisional).

\footnotetext{
1 Keputusan Presiden Republik Indonesia Nomor 129 Tahun 1998 Tentang Rencana Aksi Nasional Hak-Hak Asasi Manusia Indonesia.

2 Suparman Marzuki, Robohnya Keadilan: Politik Hukum HAM Era Reformasi (PUSHAM UII 2011).[18].
} 
Secara sederhana, konsep keadilan transisional dikemukakan oleh Teitel. Menurutnya masalah keadilan transisional timbul dalam konteks transisi atau suatu perubahan dalam tataran politik. Pemahaman umum tentang transisi mengandung makna normatif, yaitu adanya pergeseran rezim dari kurang demokratik menjadi lebih demokratik. Kemudian lebih lanjut oleh Teitel dikatakan fenomena transisi mengarah pada kaitan erat dalam pergeseran normatif tentang pemahaman keadilan dan peran hukum dalam konstruksi transisi. ${ }^{3}$

Keadilan transisi lahir sebagai tanggapan atas pelanggaran HAM yang dilakukan secara sistematis atau meluas. Keadilan transisi bukanlah bentuk khusus dari keadilan, tetapi merupakan proses keadilan yang ditujukan kepada masyarakat yang sedang mentransformasikan dirinya setelah mengalami periode pelanggaran HAM secara masif dan sistematis. Mekanisme dasar dari keadilan transisi tersebut adalah keadilan, kebenaran, reparasi, dan jaminan ketidak berulangan. ${ }^{4}$ Hal ini penting untuk melawan impunitas, ${ }^{5}$ memastikan pertanggungjawaban atas pelanggaran hak asasi manusia masa lalu, ganti rugi bagi para korban pelanggaran hak asasi manusia, dan memajukan reformasi institusi yang diperlukan untuk mengatasi akar penyebab perselisihan dan konflik.

Dalam mewujudkan cita-cita keadilan transisi dalam memerangi impunitas, masyarakat internasional terus menerus untuk meminta pertanggungjawaban para pemimpin politik dan militer yang dipandang sebagai komandan yang diduga

3 Ruti G. Teitel, Keadilan Transisional Sebuah Tinjauan Komprehensif(ELSAM 2004).[5].

4 Tujuan pengungkapan kebenaran adalah untuk memperoleh kejelasan tentang pelanggaran masa lalu, menciptakan ruang bagi pengakuan masyarakat tentang apa yang terjadi, mengapa itu terjadi, dan dampak yang diderita oleh korban.Tujuan keadilan adalah untuk menuntut pertanggungjawaban pelaku pelanggaran HAM, dan berusaha mencegah pelanggaran serupa di masa depan dengan mengakhiri impunitas atas pelanggaran di masa lalu. Tujuan reparasi adalah memulihkan hak-hak korban yang disebabkan oleh pelanggaran HAM berat. Yang terkahir adalah reformasi institusi untuk mengubah institusi militer, polisi, dan institusi negara yang terkait, dari institusi yang digunakan sebagai alat penindasan dan korupsi menjadi alat pelayanan publik yang memiliki integritas. Lihat di ICTJ dan KontraS, Keluar Jalur Keadilan: Transisi di Indonesia Setelah Jatuhnya Soeharto (ICTJ dan KontraS 2011).[8-9].

5 Impunitas didefinisikan sebagai ketidakmungkinan, secara de jure atau de facto, untuk membawa para pelaku pelanggaran ke pengadilan baik dalam proses pidana, perdata, administratif, atau disipliner karena mereka tidak tunduk pada penyelidikan yang dapat menyebabkan mereka dituduh, ditangkap, diadili dan, jika terbukti bersalah, dijatuhi hukuman yang sesuai, dan melakukan reparasi untuk korban mereka. Lihat ibid. 
bertanggungjawabdalamkasuspelanggaranberatHAMmelaluipertanggungjawaban individu ataupun pertanggungjawaban komando yang dilaksanakan dengan berbagai macam jenis peradilan. ${ }^{6}$ Penulis dalam tulisannya akan memfokuskan pembahasan bagaimana para komandan dimintai pertanggungjawaban komando mengingat sangat minimnya pembahasan doktrin tersebut.

Tanggung jawab komando merupakan bentuk pertanggungjawaban tidak langsung yang disebabkan karena gagalnya komandan atau atasan mencegah atau menghukum anak buahnya yang melakukan pelanggaran HAM berat. ${ }^{7} \mathrm{Hal}$ ini sangat berbeda dengan tanggung jawab yang muncul dari sebuah perintah. Apabila seorang komandan atau atasan memerintahkan anak buahnya untuk melakukan kejahatan, maka komandan atau atasan ini mempunyai tanggung jawab langsung atas kejahatan tersebut. ${ }^{8}$

Upaya negara merumuskan UU No. 26 tahun 2000 sebagai sarana untuk menuntut pertanggungjawaban komando melalui Pasal 42 atas pelanggaran HAM berat menyiratkan adanya pengakuan telah terjadi pelanggaran tersebut dalam batas wilayah kedaulatannya. Berdasarkan kedaulatannya, negara Indonesia mempunyai kekuasaan untuk menetapkan hukum sekaligus menegakkannya dengan cara mengadili para pelaku. Namun sayangnya UU No. 26 Tahun 2000 masih memiliki beberapa permasalahan dalam menyelesaikan pelanggaran ham berat khususnya dalam merumuskan pertanggungjawaban komando. Hal tersebut terlihat dalam penyelesaian kasus Tanjung Priok yang akan dibahas di dalam tulisan ini.

Penulis berpendapat bahwa dengan adanya masalah tersebut menyebabkan banyak komandan militer dan sipil yang bertanggung jawab secara komando dapat bebas dan akhirnya menghadirkan adanya impunitas. Hal tersebut sudah dipastikan akan berlawanan dengan agenda reformasi. Tulisan ini menjadi sebuah tinjauan hukum dalam penerapan prinsip pertanggungjawaban komando dalam melaksanakan agenda reformasi hingga masa kini.

\footnotetext{
2006).[44].

Atikah Nuraini, et. al., Hukum Pidana Internasional dan Perempuan (Komnas Perempuan

7 Joko Setiyono, 'Penerapan Pertanggungjawaban Komando di Indonesia Atas Pelanggaran HAM Berat Kategori Kejahatan Terhadap Kemanusiaan’ (2010) 39 Masalah-Masalah Hukum.[352].

8 Atikah Nuraini, et. al., Loc.Cit.
} 


\section{Doktrin Tanggung Jawab Komando dalam Hukum Humaniter Internasional dan Kaitannya dengan Keadilan Transisi}

Dalam membahas mengenai latar belakang lahirnya pertanggungjawaban komando dalam pelanggaran HAM berat, hal tersebut tidak terlepas dari awal perkembangan hukum humaniter internasional (HHI). Hugo Grotius dalam bukunya De Jure Belli Ac Pacis 1625 menyatakan bahwa negara dan pejabat yang berkuasa bertanggung jawab atas kejahatan yang diperbuat oleh orang yang berada di bawah kekuasaan efektifnya. ${ }^{9}$ Diskusi tersebut berkembang dalam Konvensi Den Haag tahun 1899 yang membahas tentang Hukum dan Kebiasaan Perang. Dalam Konvensi tersebut, Pasal 43 mengatur mengenai kewajiban pasukan dan pendudukannya untuk melakukan usaha-usaha yang sesuai dengan kewenangannya dalam mengembalikan keadaan dan menjamin ketertiban umum serta keamanan di wilayah pendudukannya. Hal yang penting juga terlihat di dalam Konvensi Den Haag (X) 1907 yang mengatur kewajiban para komandan di saat perang. Konvensi tersebut mewajibkan adanya komandan yang bertanggung jawab atas perbuatan bawahannya. ${ }^{10}$

Sejarah pertanggungjawaban komando berkembang lebih jauh pada pasca PD II, melalui Tokyo Tribunal yang menangani perkara Jenderal Tomoyuki Yamashita. Dalam persidangan tersebut, Yamashita memberikan pembelaan bahwa pasukannya dalam keadaan kacau balau, terputus hubungan koneksinya dengan posisi yang jauh dari pasukan yang melakukan kejahatan, dan tidak mengetahui perbuatan pasukannya. Namun Mahkamah Militer tetap mempertimbangkan bahwa Yamashita bertanggungjawab hanya dengan pertimbangan bahwa ia adalah komandan pasukan tersebut. ${ }^{11}$

Pertanggungjawaban komando berkembang dalam doktrin dan praktik yang kemudian melembaga secara normatif dalam hukum internasional. Hal tersebut

\footnotetext{
9 Geoffrey Robertson, Kejahatan Terhadap Kemanusiaan: Perjuangan Untuk Mewujudkan Keadilan Global (Komnas HAM 2000).[67].

${ }^{10}$ Eddy Djunaedi Karnasudirdja, Tanggung Jawab Seorang Atasan Terhadap Bawahan yang Melakukan Pelanggaran HAM Berat dan Penerapannya oleh Pengadilan Pidana Internasional dan Pengadilan Hak Azasi Manusia Indonesia (Tatanusa 2006).[9-10].

11 ibid.[12].
} 
dapat dilihat dalam Pasal 86 ayat ke (2) Protokol Jenewa I Tahun 1977, ${ }^{12}$ Pasal 7 ayat (3) International Criminal Tribunal for The Former Yugoslavia Statute(ICTY), Pasal 6 ayat (3) International Criminal Tribunal For Rwanda (ICTR) Statute, ${ }^{13}$ dan Pasal 28 Rome Statute. ${ }^{14}$ Di dalam Statuta Roma terlihat perbedaan dengan adanya tambahan mengenai pertanggungjawaban atasan selain militer.

Contoh kasus yang pernah ditangani oleh pengadilan Internasional adalah seperti yang ditangani oleh ICTY dalam perkara Karadzic dan Mladic (1996) berkesimpulan bahwa Radovan Karadzic dan Ratko Mladic gagal mengambil langkah yang diperlukan dan wajar dalam mencegah terjadi tindakan yang dilakukan oleh militer dan polisi Bosnia Serbia. Sementara itu Zejnil Delalic, Zdravko Mucic dan Hazim Delic dijatuhi pertanggungjawaban komando karena ketiganya

${ }^{12}$ Pasal 86 ayat ke (2) Protokol Jenewa I Tahun 1977: "The fact that a breach of the convention or of this protocol was committed by a subordinate does not absolute his superiors from penal or disciplinary, as the case may be if they knew, or had information which should haue enabled them to conclude in the circumstances at the time, that he was committing or was going to commit such a breach and if they did not take all reasonable measures within their power to prevent or repress the breach".

${ }_{13}$ Pasal 7 ayat (3) International Criminal tribunal for The Former Yugoslavia Statute dan Pasal 6 ayat (3) International Criminal Tribunal For Rwanda (ICTR) Statute: "The fact that any of the acts referred to in articles 2 to 5 of the present statute was committed by a subordinate does not relieve his superior of criminal responsibility if he knew or had reason to know that the subordinate was about to commit such acts or had done so and the superior failed to take the necessary and reasonable measures to prevent such acts".

${ }_{14}$ Pasal 28 Rome Statute: In addition to other grounds of criminal responsibility under this Statute for crimes within the jurisdiction of the Court: (a) A military commander or person effectively acting as a military commander shall be criminally responsible for crimes within the jurisdiction of the Court committed by forces under his or her effective command and control, or effective authority and control as the case may be, as a result of his or her failure to exercise control properly over such forces, where: (i) That military commander or person either knew or, owing to the circumstances at the time, should have known that the forces were committing or about to commit such crimes; and (ii) That military commander or person failed to take all necessary and reasonable measures within his or her power to prevent or repress their commission or to submit the matter to the competent authorities for investigation and prosecution. (b) With respect to superior and subordinate relationships not described in paragraph (a), a superior shall be criminally responsible for crimes within the jurisdiction of the Court committed by subordinates under his or her effective authority and control, as a result of his or her failure to exercise control properly over such subordinates, where: (i) The superior either knew, or consciously disregarded information which clearly indicated, that the subordinates were committing or about to commit such crimes; (ii) The crimes concerned activities that were within the effective responsibility and control of the superior; and (iii) The superior failed to take all necessary and reasonable measures within his or her power to prevent or repress their commission or to submit the matter to the competent authorities for investigation and prosecution. 
berada pada posisi sebagai atasan pelaku-pelaku kejahatan. ${ }^{15}$ Selain itu ada juga kasus yang dilakukan oleh mantan pemimpin pemberontak Kongo, Jean-Pierre Bemba, dihukum penjara 18 tahun oleh International Criminal Court (ICC) terkait kejahatan perang dan kekerasan seksual. Bemba dianggap gagal menghentikan milisi pimpinannya dalam melakukan pembunuhan dan perkosaan. ${ }^{16}$

Prinsip hukum tentang tanggung jawab komando ini merupakan prinsip yang penting dalam penyelenggaraan pengadilan terhadap kasus pelanggaran berat hak asasi manusia yang acap melibatkan para pemimpin politik dan militer sebagai salah tujuan dari keadilan transisi yang memiliki kedudukan di dalam hukum internasional. Seperti yang sudah dijelaskan sebelumnya bahwa keadilan transisi memiliki empat jendela. Salah satu jendela tersebut adalah adanya peradilan yang bertujuan untuk menuntut pertanggungjawaban pelaku pelanggaran HAM, dan berusaha mencegah pelanggaran serupa di masa depan dengan mengakhiri impunitas atas pelanggaran di masa lalu. Seorang komando atau atasan harus selalu menjalankan fungsi pengendalian terhadap bawahan, mengarahkan dan memberi petunjuk kepada bawahan, mengawasi pelaksanaan tugas, dan mengambil tindakan disiplin apabila terjadi kesalahan dalam menjalankan tugas ${ }^{17}$ Maka dari itu, apabila komandan lalai dalam melakukan kewajiban tersebut, seharusnya ia dapat dimintai pertanggungjawaban pidana.

\section{Prinsip-Prinsip dalam Penerapan Doktrin Pertanggungjawaban Komando}

Doktrin Pertanggungjawaban Komando menjadi dasar hukum bagi komandan militer, atasan sipil, atau individu lain yang berada dalam posisi atasan atau pemegang kekuasaan komando lainnya untuk bertanggung jawab secara pidana atas kelalaian atau kegagalannya untuk melaksanakan pengendalian terhadap anak buahnya sehingga terjadi kejahatan Internasional. Kegagalan bertindak (failure to

15 P.L.T. Sihombing, 'Pertanggung Jawaban Komando' (2004) 2 Jurnal HAM.[69].

16 Gheanina Prisilia Kaban, 'Unsur-Unsur Tanggung Jawab Komando Di Dalam Hukum Pidan Internasional: Studi Putusan The Prosecutor V. Jean-Pierre Bemba Gombo/ICC-01/05-01/08' (2018) 1 Jurnal Ilmu Hukum Alethea.[158].

${ }^{17}$ Atikah Nuraini, et.al., Op.Cit. [50]. 
act) ini dikatakan sebagai tindakan pembiaran (omission $){ }^{18}$ sehingga komandan harus bertanggung jawab. ${ }^{19}$ Bentuk tanggung jawab komando ini berbeda dengan bentuk pertanggungjawaban pidana secara individu yang dapat dikenakan kepada komandan atau atasan apabila ia ikut merencanakan, menghasut, memerintahkan, membantu, melakukan, dan turut serta melakukan kejahatan. Dalam hal pertanggungjawaban komando, maka haruslah ada beberapa elemen berikut, yaitu: ${ }^{20}$

1. Ada hubungan atasan dan bawahan dalam pengendalian efektif (a superiorsubordinate relationship);

a. Hubungan langsung

b. Hubungan tidak langsung (mengikuti hierarki rantai komando)

2. Pengetahuan atasan terhadap kejahatan yang dilakukan oleh bawahannya (mens rea);

3. Adanya failure to act yaitu tindakan yang gagal diambil untuk mencegah, menghukum serta menghentikan tindak pidana yang dilakukan bawahannya. (actus reus).

Berdasarkan precedents, hubungan atasan dan bawahan dapat didasarkan atas dasar de jure dan de facto. Yang dimaksud de jure adalah pengangkatan seseorang yang dilakukan melalui jalur formal dengan adanya peraturan yang mengatur hubungan atasan dan bawahan beserta tugas masing-masing. Sedangkan yang dimaksud de facto adalah hubungan antara atasan dan bawahan yang dilihat dari kenyataan di lapangan. ${ }^{21}$

Dalam beberapa kasus yang diadili oleh ICTR dan ICTY para terdakwa sebagai seorang atasan oleh karena dalam kenyataannya secara de facto mereka dianggap sebagai pemimpin oleh kesatuannya yang menunjukkan otoritas sebagai seorang atasan. Seperti kasus ICTR dalam menangani Akeyasu yang dianggap

18 Delik omisi menurut Remmelink adalah suatu perbuatan atau sikap tindak yang tidak melakukan atau melalaikan sebuah kewajiban atau perintah hukum. Lihat Jan Remellink, Hukum Pidana: Komentar Atas Pasal-Pasal Terpenting Dari KUHP Belanda dan Padanannya Dengan KUHP Indonesia (Gramedia Pustaka Utama 2003).[78].

19 Muladi, Statuta Roma Tahun 1998 tentang Mahkamah Pidana Internasional Dalam Kerangka Hukum Pidana Internasional dan Implikasinya Terhadap Hukum Pidana Nasional (Alumni 2001).[151].

${ }^{20}$ P.L.T. Sihombing, Op.Cit.[70].

21 ibid. 
mempunyai otoritas de jure dan de facto baik terhadap golongan sipil, polisi, maupun tentara $^{22}$ dan kasus yang ditangani oleh ICTY bahwa terdakwa Mucic dan Delic dianggap sebagai atasan dan dipersalahkan karena secara de facto berkuasa dan tidak menghukum bawahannya yang melakukan kejahatan terhadap para tahanan. ${ }^{23}$ Walau tidak adanya pengangkatan de jure terhadap para terdakwa, namun dalam kenyataannya terdakwa dianggap sebagai pemimpin. Dalam hal ini para terdakwa terbukti mempunyai kewenangan untuk mengendalikan bawahannya, terdapat rantai hierarki, adanya kebiasan mengeluarkan perintah-perintah yang dipatuhi oleh kesatuannya, dan dapat menghukum bawahannya. Pengangkatan De Jure belum tentu kuat dalam menentukan apakah adanya pengendalian efektif sehingga memerlukan adanya bukti de facto bahwa seseorang tersebut memang memegang kendali atas bawahannya tersebut. Bahkan dalam beberapa kasus, jika bukti de facto saja telah meyakinkan bahwa seseorang memang mengendalikan bawahannya, orang tersebut memenuhi unsur adanya hubungan atasan dan bawahan. ${ }^{24}$

Unsur kedua untuk dapat mempersalahkan seorang atasan atas perbuatan bawahannya adalah pengetahuannya. Pengetahuan komandan adalah merupakan mens rea ${ }^{25}$ dalam tindak kejahatannya. Terminologi dalam "mengetahui perbuatan" mengenal beberapa tingkatan, dari yang ringan seperti "actual knowledge" sampai yang lebih berat seperti "had reason to know" dan "should have known". Wewenang de jure tidak dapat membuktikan kontrol efektif, karena tidak dapat membuktikan pengetahuan yang dimiliki. ${ }^{26}$

Dalam berbagai kasus yang diperiksa oleh ICTR dan ICTY mengenai kadar mengetahui seseorang, tidak perlu bahwa terdakwa bertindak dengan sadar untuk dapat dipersalahkan, cukuplah bahwa ia mempunyai alasan untuk mengetahui bahwa bawahannya akan atau sedang melakukan kejahatan dan ia tidak melakukan usaha

${ }^{22}$ ICTR, The Prosecutor v. Jean-Paul Akayesu, ICTR-96-4-T, Trial Chamber 1, 2 September 1998.

${ }^{23}$ ICTY, The Prosecutor v. Zejnil Delalic, Hazim Delic, IT-96-21-T, 16 November 1998.

${ }^{24}$ Eddy Djunaedi Karnasudirdja, Op.Cit.[56].

25 "Mens rea" dipersamakan dengan "guilty knowledge atau criminal intent". Lihat David Lanius, Strategic Indeterminacy in the Law (Oxford University Press 2019).[113].

${ }^{26}$ Eddy Djunaedi Karnasudirdja, Loc.Cit.[60]. 
yang semestinya. Para Penuntut harus memberikan bukti akan adanya pengetahuan tersebut. Keberadaan dari pengetahuan seperti itu tidak dapat hanya diasumsikan. ${ }^{27}$

Unsur yang terakhir adalah actus reus ${ }^{28}$ dalam pertanggungjawaban komando yaitu seorang atasan gagal dalam mencegah, menghentikan, atau menghukum atas kejahatan yang dilakukan oleh bawahannya. Dari putusan-putusan Pengadilan Pidana Internasional seperti ICTR dan ICTY dapat disimpulkan bahwa seorang atasan yang telah membuktikan bahwa ia telah mengusahakan pencegahan sedapat mungkin dengan kemampuan yang ada dapat membebaskan seseorang dari tanggung jawab atas perbuatan bawahannya. Usaha yang dilakukan adalah usaha yang wajar dan bisa dilaksanakan dalam waktu itu. Seorang atasan tidak diwajibkan melakukan hal yang mustahil atau tidak mungkin dilaksanakan. Komandan memiliki kewajiban hukum dengan kekuasaan yang dimiliki dalam menghentikan (to suppres), mencegah (to prevent), menindak (to repress), melapor (to report). ${ }^{29}$

Pertanggungjawaban komando dapat diterapkan pada seluruh komando pada rantai komando (Unity of Command). Komentar Pasal 87 dan dalam kaitannya dengan Pasal 86 ke 2 Protokol I Tahun 1977 menegaskan responsibility of the commanders: $:^{30}$

"...this responsibility applies from the highest to the lowest level of the hierarchy, from the commander in chief down to the common soldier who take ouer as a head of the platoon..,"

Pelaksanaan dalam praktik. pertanggungjawaban komando diterapkan sampai pada presiden ("...covering any superior in a line of command... "). ${ }^{31}$

Persoalan lain adalah syarat adanya kejahatan yang dilakukan oleh anggota militer di bawah komandonya atau orang yang berada di bawah pengendaliannya. Ada yang berpendapat bahwa harus ada terlebih dahulu putusan pengadilan atas kejahatan yang dilakukan oleh bawahan. Sesuai dengan perkembangan doktrin

\footnotetext{
27 ibid.

28 "Actus reus" adalah terminologi latin dari "guilty act". Lihat David Lanius, Op.Cit.[113].

${ }^{29}$ P.L.T. Sihombing, Op.Cit.[71].

${ }^{30}$ International Committee of The Red Cross, Commentary on the Additional Protocols to the Geneva Conventions, (Martinus Nijhoff Publishers 1987).[1019].

31 ibid.
} 
bahwa pertanggungjawaban komando dapat diterapkan apabila telah ada putusan pengadilan atau secara material terdapat bukti-bukti bahwa bawahan atau orang yang berada di bawah pengendaliannya terlibat kejahatan. Namun demikian, dalam praktik pemeriksaan kasus jenderal Tomoyuki Yamashita, Admiral Soemu Toyoda, Karadzic, Delalic, Mucic dan Delic, pertanggungjawaban komando diterapkan walaupun tidak ada putusan pengadilan atas pelanggaran yang dilakukan anak buahnya tetapi terdapat bukti-bukti materiil bahwa anak buah di bawah komandonya atau orang yang berada dibawah pengendaliannya telah terlibat melakukan pelanggaran/kejahatan.

\section{Analisis Pengaturan Pertanggungjawaban Komando Dalam Peraturan Nasional}

Dalam peraturan nasional, pertanggungjawaban komando diatur dalam Pasal 42 Undang-Undang No. 26 Tahun 2000 Tentang Pengadilan Hak Asasi Manusia. ${ }^{32}$ Dalam rumusannya, Pasal 42 ayat (1) UU Pengadilan HAM tidak mengadopsi secara utuh Pasal 28A Statuta Roma yang menjadi acuan dari pembentukan undangundang tersebut sebagaimana dijelaskan dalam penjelasan Pasal 7 UU Pengadilan

${ }^{32}$ Pasal 42 UU No. 26 Tahun 2000: “(1) Komandan militer atau seseorang yang secara efektif bertindak sebagai komandanmiliter dapat dipertanggungjawabkan terhadap tindak pidana yang berada di dalam yurisdiksi Pengadilan HAM, yang dilakukan oleh pasukan yang berada di bawah komando dan pengendaliannya yang efektif, atau di bawah kekuasaan dan pengendaliannya yang efektif dan tindak pidana tersebut merupakan akibat dari tidak dilakukan pengendalian pasukan secara patut, yaitu :a. komandan militer atau seseorang tersebut mengetahui atau atas dasar keadaan saat itu seharusnya mengetahui bahwa pasukan tersebut sedang melakukan atau baru saja melakukan pelanggaran hak asasi manusia yang berat; dan b. komandan militer atau seseorang tersebut tidak melakukan tindakan yang layak dan diperlukan dalam ruang lingkup kekuasaannya untuk mencegah atau menghentikan perbuatan tersebut atau menyerahkan pelakunya kepada pejabat yang berwenang untuk dilakukan penyelidikan, penyidikan, dan penuntutan. (2) Seorang atasan, baik polisi maupun sipil lainnya, bertanggung jawab secara pidana terhadap pelanggaran hak asasi manusia yang berat yang dilakukan oleh bawahannya yang berada di bawah kekuasaan dan pengendaliannya yang efektif, karena atasan tersebut tidak melakukan pengendalian terhadap bawahannya secara patut dan benar, yaitu :a. atasan tersebut mengetahui atau secara sadar mengabaikan informasi yang secara jelas menunjukkan bahwa bawahan sedang melakukan atau baru saja melakukan pelanggaran hak asasi manusia yang berat; dan b. atasan tersebut tidak mengambil tindakan yang layak dan diperlukan dalam ruang lingkup kewenangannya untuk mencegah atau menghentikan perbuatan tersebut atau menyerahkan pelakunya kepada pejabat yang berwenang untuk dilakukan penyelidikan, penyidikan, dan penuntutan. (3) Perbuatan sebagaimana dimaksud dalam ayat (1) dan ayat (2) diancam dengan pidana yang sama sebagaimana dimaksud dalam Pasal 36, Pasal 37, Pasal 38, Pasal 39, dan Pasal 40”. 
HAM. ${ }^{33}$ Terdapat beberapa kesalahan penafsiran Pasal 28a Statuta Roma pada Pasal 42 ayat (1) yang menyebabkan konsekuensi hukum penerapan pertanggungjawaban komando di Indonesia belum maksimal. Pasal 28a Statuta Roma menyatakan “ $A$ military commander or person effectively acting as a military commander shall be criminally responsible for crimes... " yang kemudian ditafsirkan dalam Pasal 42 ayat (1) menjadi "Komando militer atau seseorang yang secara efektif bertindak sebagai komandan militer dapat dipertanggungjawabkan terhadap tindak pidana yang berada dalam yurisdiksi pengadilan HAM, yang dilakukan oleh pasukan yang berada dibawah komando dan pengendaliannya yang efektif,...." Ada beberapa permasalahan dalam tafisran tersebut. ${ }^{34}$ Pertama, Pasal 42 ayat (1) UU Pengadilan HAM tidak menafsirkan dengan benar mengenai frasa "effectively". Tafsiran dalam rumusan pasal tersebut seharusnya adalah "secara nyata" atau "yang nyata-nyata, yang sungguh-sungguh" bukan “yang secara efektif”. Hal ini berkonsekuensi pada distorsi konstruksi hukum sebab secara konseptual dalam Statuta Roma disebutkan yang dimaksud "pengendalian efektif' dalam pasal ini diartikan sebagai adanya tindakan pengendalian yang nyata atau dengan kata lain merupakan pengendalian secara de facto (nyata). ${ }^{35}$

Kedua, berkenaan dengan terjemahan frasa "shall", yang dapat diartikan sebagai "wajib” diubah menjadi “dapat”. Hal ini memiliki konsekuensi bahwasannya pertanggungjawaban komando adalah sesuatu yang fakultatif atau opsional, dan bukanlah sesuatu yang imperatif atau wajib. Sehingga apabila ada suatu peristiwa yang menuntut adanya pertanggungjawaban komando dan pelaku tidak diadili adalah suatu hal yang normal, karena memang diberi opsi untuk tidak diadili. ${ }^{36}$ Ketiga adalah bahwa dalam rumusan Pasal 42 ayat (1) tidak dimasukkan frasa “criminally responsible" sebagaimana terdapat dalam Pasal 28a Statuta Roma. Konsekuensinya adalah bahwa bisa saja seorang komandan militer tidak diadili

\footnotetext{
${ }^{33}$ Indonesia, Undang-Undang Pengadilan Hak Asasi Manusia, UU No. 26 Tahun 2000, LN No.208 Tahun 2000, TLN No. 4026, Penjelasan Ps.7.

${ }^{34}$ Suparman Marzuki, Op.Cit.[411].

35 ibid.

${ }^{36}$ ibid.
} 
secara pidana, tetapi dalam ranah peradilan lain misalnya secara administratif atau dalam konteks riil adalah dalam peradilan militer. ${ }^{37}$ Perubahan penafsiran "shall" menjadi "dapat" dan juga penghilangan frasa "criminally responsible" sungguh melemahkan konsep pertanggungjawaban komando.

Hal ini diperkeruh dengan belum adanya revisi terhadap UU Peradilan Militer yang turut berkontribusi terhadap impunitas komandan militer. Terdapat beberapa permasalahan dalam UU Peradilan Militer yang menjadi legitimasi atas pelemahan pertanggungjawaban komando. Pertama, dalam UU Peradilan Militer mendasarkan suatu kesalahan berdasarkan subjek hukum, bukan delik. Hal ini terlihat dalam Pasal 9 ayat 1 UU Peradilan Militer ${ }^{38}$ yang menjelaskan peradilan militer mengadili tindak pidana yang dilakukan oleh militer. Dalam rumusan pasal tersebut tidak dijelaskan jenis tindak pidana apa saja yang masuk ke dalam lingkup peradilan militer, sehingga hal ini menimbulkan subjektivitas kompetensi yang berakibat pada keleluasaan militer untuk mengadili semua perkara termasuk pelanggaran HAM di dalam peradilan militer. ${ }^{39}$ Hal ini menimbulkan kebingungan dan kerancuan serta menyalahi semangat pemisahan pengadilan berdasarkan kejahatan/delik, bukan subjek. Subjektivitas kompetensi dalam UU Peradilan Militer pun semakin diperkuat dengan rumusan Pasal 199 ayat (1) ${ }^{40}$ bahwasannya untuk menentukan apakah sebuah kasus perlu diadili di pengadilan militer atau pengadilan umum ditentukan melalui kesepakatan dan musyawarah. Selain itu keputusan untuk

\footnotetext{
37 ibid.

38 Pasal 9 ayat (1) UU Peradilan Militer:"Pengadilan dalam lingkungan peradilan militer berwenang: 1. Mengadili tindak pidana yang dilakukan oleh seseorang yang pada waktu melakukan tindak pidana adalah: a. Prajurit; b. yang berdasarkan undang-undang dipersamakan dengan Prajurit; c. anggota suatu golongan atau jawatan atau badan atau yang dipersamakan atau dianggap sebagai Prajuritberdasarkan undang-undang; d. seseorang yang tidak masuk golongan pada huruf a, huruf $b$, dan huruf $c$ tetapi atas keputusan Panglima dengan persetujuan Menteri Kehakiman harus diadili oleh suatu Pengadilan dalam lingkungan peradilan militer".

${ }^{39}$ KontraS, Menerobos Jalan Buntu: Kajian Terhadap Sistem Peradilan Militer di Indonesia, cet.1 (KontraS 2009).[52].

${ }^{40}$ Pasal 199 ayat (1) UU Peradilan Militer: "Untuk menetapkan apakah pengadilan dalam lingkungan peradilan militer atau pengadilan dalam lingkungan peradilan umum yang akan mengadili perkara pidana sebagaimana dimaksud dalam Pasal 198 ayat (1), diadakan penelitian bersama oleh jaksa/jaksa tinggi dan oditur atas dasar hasil penyidikan tim sebagaimana dimaksud dalam Pasal 198 ayat (2)".
} 
mengadili di pengadilan militer atau pengadilan umum ditentukan oleh kerugian yang muncul akibat dari kejahatan yang terjadi sebagaimana dijelaskan dalam Pasal 200 UU Peradilan Militer. ${ }^{41}$ Jika kerugian banyak terjadi di pihak militer maka pengadilan dilakukan di pengadilan militer dan berlaku sebaliknya. Hal ini lagi-lagi menunjukkan subjektivitas kompetensi yang menimbulkan ketidakpastian hukum serta pelemahan pertanggungjawaban komando. ${ }^{42}$ Permasalahan ini muncul dalam kasus Semanggi I dan II di mana Tim Ad Hoc Penyelidik Pro Justisia Komnas HAM menemukan adanya pelanggaran berat HAM, yakni kejahatan terhadap kemanusiaan. Sejumlah pejabat militer diduga bertanggungjawab dalam peristiwa tersebut, salah satunya Jenderal Wiranto. Kemudian Jaksa Agung menolak untuk menyidik kasus tersebut dikarenakan para prajurit yang didakwa telah diadili di peradilan militer. Jaksa Agung pun berargumen apabila kasus ini dibawa ke pengadilan Ad Hoc HAM maka akan ne bis in idem yaitu seseorang diadili dua kali atas dakwaan yang sama. ${ }^{43}$ Secara argumentasi pernyataan Jaksa Agung tersebut menyesatkan, namun secara legal-formal hal itu juga dibenarkan dikarenakan UU Peradilan Militer membolehkan hal itu terjadi.

Kelemahan selanjutnya adalah bahwa dalam Pasal 42 ayat (1) b UU Pengadilan HAM yang menyatakan "Komandan militer atau seseorang tersebut tidak melakukan tindakan yang layak dan diperlukan dalam ruang lingkup kekuasaannya untuk

\footnotetext{
${ }^{41}$ Pasal 200 UU Peradilan Militer:“(1) Apabila menurut pendapat sebagaimana dimaksud dalam Pasal 199 ayat (3) titik berat kerugian yang ditimbulkan oleh tindak pidana tersebut terletak pada kepentingan umum dan karenanya perkara pidana itu harus diadili oleh Pengadilan dalam lingkungan peradilan umum, Perwira Penyerah Perkara segera membuat surat keputusan penyerahan perkara yang diserahkan melalui Oditur kepada Penuntut Umum, untuk dijadikan dasar mengajukan perkara tersebut kepada Pengadilan Negeri yang berwenang. (2) Apabila menurut pendapat sebagaimana dimaksud pada ayat (1), titik berat kerugian yang ditimbulkan oleh tindak pidana tersebut terletak pada kepentingan militer sehingga perkara pidana itu harus diadili oleh Pengadilan dalam lingkungan peradilan militer, pendapat sebagaimana dimaksud dalam Pasal 199 ayat (3) dijadikan dasar bagi Oditur Jenderal untuk mengusulkan kepada Menteri, agar dengan persetujuan Menteri Kehakiman dikeluarkan keputusan Menteri yang menetapkan, bahwa perkara pidana tersebut diadili oleh Pengadilan dalam lingkungan peradilan militer. (3) Surat keputusan sebagaimana dimaksud pada ayat (2) dijadikan dasar bagi Perwira Penyerah Perkara dan Jaksa/Jaksa Tinggi untuk menyerahkan perkara tersebut kepada Pengadilan Militer/Pengadilan Militer Tinggi”.

${ }^{42}$ KontraS, Op.Cit. [56].

${ }^{43}$ Abdul Hakim G Nusantara, 'Sebuah Upaya Memutus Impunitas: Tanggung Jawab Komando Dalam Pelanggaran Berat Hak Asasi Manusia’ (2004) Vol 2 No.2 Jurnal HAM.[14] .
} 
mencegah..." tidak dijelaskan mengenai definisi dan batasan yang tegas tentang apa yang "layak" dan "perlu" dilakukan oleh penanggung jawab komando. Sehingga memberikan ruang penafsiran yang luas dan melemahkan kewajiban komandan militer untuk melakukan pencegahan. Pasal ini juga memiliki konsekuensi bahwa proses dalam pengadilan mengutamakan pada pembuktian tindakan yang dilakukan sudah layak atau tidak (obligation of conduct) dan mengesampingkan pembuktian bahwa apakah tindakan yang diambil berhasil mencegah atau menghentikan kejahatan atau tidak (obligation of result). ${ }^{44}$ Padahal, elemen dari pertanggungjawaban komando salah satunya ialah adanya failure to act yaitu tindakan yang gagal diambil untuk mencegah, menghukum serta menghentikan tindak pidana yang dilakukan bawahannya (actus reus $)^{45}$ Tidak hanya secara materiil peraturan yang bermasalah, secara penegakan hukum pun terdapat beberapa kendala yang juga diakibatkan oleh tidak jelasnya pengaturan materiil. Seperti misalnya kesulitan mengumpulkan alat bukti, impunitas terhadap jenderal ataupun presiden dengan tidak memasukkannya ke dalam pihak yang bertanggungjawab, serta putusan yang tidak sinkron dengan dakwaan dan tuntutan. ${ }^{46}$

Kelemahan berikutnya adalah bahwa dalam Pasal 10 UU No.26 Tahun $2000^{47}$ dinyatakan hukum acara yang digunakan untuk menangani perkara pelanggaran HAM berat adalah sesuai dengan ketentuan hukum acara pidana (KUHAP). Padahal KUHAP adalah suatu ketentuan hukum acara pidana yang diperuntukkan untuk kejahatan tindak pidana biasa (ordinary crimes) sedangkan pelanggaran HAM berat merpakan kejahatan tindak pidana luar biasa (extraordinary crimes). Hal ini menimbulkan konsekuensi hukum yang cukup serius dalam penanganan kasus pelanggaran HAM berat. Contohnya adalah prinsip yang dianut dalam Pasal 185 ayat (2) KUHAP ${ }^{48}$ tentang satu saksi bukanlah saksi. Prinsip ini sulit dibuktikan

\footnotetext{
${ }^{44}$ Suparman Marzuki, Op.Cit.[413].

45 P.L.T. Sihombing, Op.Cit.[70].

46 ibid.[72].

47 Pasal 10 UU No.26 Tahun 2000 menyatakan: "Dalam hal tidak ditentukan lain dalam Undang-undang ini, hukum acara atas perkara pelanggaran hak asasi manusia yang berat dilakukan berdasarkan ketentuan hukum acara pidana".

${ }^{48}$ Pasal 185 ayat (2) KUHAP menyatakan: "Keterangan seorang saksi saja tidak cukup untuk membuktikan bahwa terdakwa bersalah terhadap perbuatan yang didakwakan kepadanya".
} 
terhadap pelanggaran HAM berat misalnya pemerkosaan, atau pun penganiayaan secara diam-diam dalam konflik perang atau pun kerusuhan massa yang mana adalah kejahatan tersebut meluas dan sistematik. ${ }^{49}$

\section{Analisis Penerapan Tanggung Jawab Komando dalam Kasus Pelanggaran HAM Berat di Tanjung Priok}

Kasus ini bermula pada 7 September 1984 di mana Anggota Babinsa Koja Selatan bernama Hermanu mendatangi suatu masjid dan mencopot poster wanita berjilbab dengan koran yang dicelup air got. Warga pun melihat dan tersulut kemarahannya, dan membakar sepeda motor Hermanu. Atas peristiwa pembakaran tersebut, terjadilah penangkapan terhadap beberapa warga yang terlibat dalam pembakaran yang kemudian ditahan di Kodim Jakarta Utara. Kemudian pada tanggal 12 September 1984, Amir Biki seorang tokoh masyarakat setempat pun mengerahkan massa ke Kodim Jakarta Utara untuk menuntut pembebasan warga yang ditahan. Massa yang dipimpin oleh Amir Biki pun dihadang oleh militer, situasi pun memanas dan terjadi baku tembak yang memakan korban jiwa hingga ratusan orang. Pasca kejadian tersebut, terjadi penangkapan sewenang-wenang terhadap orang-orang yang dicurigai terlibat dalam peristiwa bentrokan tersebut. ${ }^{50}$ Komnas HAM pun membentuk Komisi Penyelidikan dan Pemeriksaan Pelanggaran HAM di Tanjung Priok (KP3T) pada tahun 2000, dan hasil temuan serta rekomendasi dari KP3T adalah antara lain telah terjadi pelanggaran HAM berat dan bahwa terdapat pertanggungjawaban komando. ${ }^{51}$ Kasus ini pun diadili dalam Pengadilan Ad Hoc HAM dan JPU secara umum membuat 4 dakwaan yakni terhadap Letkol R.A.Butar-Butar, Kol.CPM Pranowo, Sriyanto, dan Serda Sutrisno Mascung $\mathrm{dkk}^{52}$ yang didakwa telah melakukan kejahatan terhadap kemanusiaan berupa pembunuhan, percobaan pembunuhan, perampasan kebebasan

\footnotetext{
49 Suparman Marzuki, Op.Cit.[417].

${ }^{50}$ Suparman Marzuki, Op.Cit.[571].

${ }^{51}$ Komisi Penyelidikan dan Pemeriksaan Pelanggaran Hak Asasi Manusia di Tanjung Priok (KP3T), "Ringkasan Eksekutif Hasil Penyelidikan," http://jdih.komnasham.go.id/assets/uploads/ files/info_hukum/eksum\%20tanjung\%20priok.pdf diakses 31 Oktober 2020.

${ }_{52}$ Terdakwa lainnya bernama Asrori, Siswoyo, Abdul Hadim, Zulfata, Soemitro, Sofyan Hadi, Prayogi, Winarko, Idrus, Muchson, dikutip dari Suparman Marzuki, Op.Cit.[571].
} 
fisik, penganiayaan dan penyiksaan sesuai dengan Pasal 9 UU Pengadilan HAM ${ }^{53}$ dengan dasar pertanggungjawaban komando sebagaimana diatur dalam Pasal 42 ayat $(1)^{54}$ UU Pengadilan HAM serta pertanggungjawaban individu sebagaimana diatur dalam Pasal $37^{55}$ UU Pengadilan HAM. ${ }^{56}$

Dalam dakwaan ini pun terdapat beberapa hal yang melemahkan penerapan konsep pertanggungjawaban komando. Pertama, JPU tidak memasukkan namanama penting yang direkomendasikan oleh KP3T seperti Mayjend TNI Try Sutrisno (Pangdam V Jaya), Brigjend TNI. Dr. Soemardi (Kepala RSPAD Gatot Subroto); Mayor TNI Darminto (Bagpam RSPAD Gatot Soebroto), Kapten Auha Kusin (Rohisdam V Jaya), dan Kapten Mattaoni (Rohisdam V Jaya) serta yang dianggap paling bertanggungjawab yakni Jend. TNI Benny Moerdani (Panglima TNI Pangkopkamtib). ${ }^{57} \mathrm{Hal}$ ini menunjukkan adanya pemangkasan pertanggungjawaban

${ }^{53}$ Pasal 9 UU No.26 Tahun 2000: "Kejahatan terhadap kemanusiaan sebagaimana dimaksud dalam Pasal 7 huruf $b$ adalah salah satu perbuatan yang dilakukan sebagai bagian dari serangan yang meluas atau sistematlk yang diketahuinya bahwa serangan tersebut ditujukan secara langsung terhadap penduduk sipil, berupa : a. pembunuhan; b. pemusnahan; c. perbudakan; d. pengusiran atau pemindahan penduduk secara paksa; e. perampasan kemerdekaan atau perampasan kebebasan fisik lain secara sewenang wenang yang melanggar (asas-asa) ketentuan pokok hukum intemasional; f. penyiksaan; g. perkosaan, perbudakan seksual, pelacuran secara paksa, pemaksaan kehamilan, pemandulan atau sterilisasi secara paksa atau bentuk-bentuk kekerasaan seksual lain yang setara; $h$. penganiayaan terhadap suatu kelompok tertentu atau perkumpulan yang didasari persamaan paham politik, ras, kebangsaan, efnls, budaya, agama, jenis kelamin atau alasan lain yang telah di,akui secara universal sebagai hal yang dilarang menurut hukum internasional; i. penghilangan orang secara paksa; atau j. kejahatan apartheid;".

${ }^{54}$ Pasal 42 ayat (1) UU No. 26 Tahun 2000: “(1) Komandan militer atau seseorang yang secara efektif bertindak sebagai komandanmiliter dapat dipertanggungjawabkan terhadap tindak pidana yang berada di dalam yurisdiksi Pengadilan HAM, yang dilakukan oleh pasukan yang berada di bawah komando dan pengendaliannya yang efektif, atau di bawah kekuasaan dan pengendaliannya yang efektif dan tindak pidana tersebut merupakan akibat dari tidak dilakukan pengendalian pasukan secara patut, yaitu :a. komandan militer atau seseorang tersebut mengetahui atau atas dasar keadaan saat itu seharusnya mengetahui bahwa pasukan tersebut sedang melakukan atau baru saja melakukan pelanggaran hak asasi manusia yang berat; dan b. komandan militer atau seseorang tersebut tidak melakukan tindakan yang layak dan diperlukan dalam ruang lingkup kekuasaannya untuk mencegah atau menghentikan perbuatan tersebut atau menyerahkan pelakunya kepada pejabat yang berwenang untuk dilakukan penyelidikan, penyidikan, dan penuntutan.

55 Pasal 37 UU No.26 Tahun 2000: "Setiap orang yang melakukan perbuatan sebagaimana dimaksud dalam Pasal 9 huruf $a, b, d$, e, dan $\mathrm{j}$ dipidana dengan pidana mati atau pidana penjara seumur hidup atau pidana penjara paling lama 25 (dua puluh lima) tahun dan paling singkat 10 (sepuluh) tahun".

${ }_{56}$ Suparman Marzuki, Op.Cit.[581].

${ }^{57}$ KontraS, Reproduksi Ketidakadilan Masa Lalu: Catatan Perjalanan Membongkar Kejahatan HAM Tanjung Priok, cet.1 (KontraS 2008).[73]. 
komando terhadap atasan tertinggi, yang menunjukkan buruknya penerapan konsep pertanggungjawaban komando di Indonesia. Tidak dimasukkannya nama-nama penting tersebut, mengakibatkan sulitnya pembuktian rangkaian komando dalam kasus ini oleh JPU dan melanggengkan impunitas dengan membebaskan para penanggungjawab komando dan pembuat kebijakan. Dalam kasus ini, nama-nama penting tersebut sejatinya dapatlah dimintai pertanggungjawaban sebagaimana dalam kasus Prosecutor vs Kordic and Cerkez disebutkan bahwa "The Appeals Chamber found that the degree of de facto authority or powers of control required under the doctrine of superior responsibility is equivalent to that required based upon de jure authority. . " "58 yang dapat disimpulkan bahwa tidak hanya komandan militer yang secara de facto saja yang dapat dikenakan pertanggungjawaban komando, bahkan pimpinan politik atau atasan sipil yang memiliki kekuasaan juga dapat dikenakan pertanggungjawaban yang sama. Hal ini sesuai dengan apa yang dipertegas dalam Komentar Pasal 87 dan dalam kaitannya dengan pasal 86 ke 2 Protokol I Tahun 1977 bahwa secara doktrin, pertanggungjawaban komando dapat diterapkan pada seluruh komando pada rantai komando.

Dalam kasus ini, argumentasi bahwa para atasan komandan militer atau nama-nama penting tersebut sepatutnya dimintai pertanggungjawabannya diperkuat oleh hasil temuan dari Tim KP3T. Dalam temuannya, KP3T menyatakan bahwa dalam kasus ini telah terjadi secara nyata pertanggungjawaban komando yang didasari oleh tiga hal. Pertama, para komandan militer seharusnya dapatlah menduga bahwa akan terjadi suatu kerusuhan besar didasari oleh fakta di lapangan telah beredar hasutan-hasutan serta perkembangan situasi yang memanas semenjak tanggal 8 September 1984. Kedua, bahwa seharusnya para atasan dan komandan militer sudah dapat mengantisipasi dengan mengambil tindakan-tindakan pencegahan seperti misalnya dialog dengan tokoh masyarakat sehingga dapat menghindari bentrok. Ketiga, para atasan dan komandan militer telah gagal mencegah terjadinya kerusuhan pada 12 September 1984 dengan

\footnotetext{
${ }^{58}$ Prosecutor v. Kordic and Cerkez, Case No. IT-95-14/2-T Judgment (Feb. 26, 2001).
} 
tidak mempersiapkan protokoler ataupun kesatuan regu dengan peralatan yang memadai (failure to act). ${ }^{59}$ Dalam laporannya, Tim KP3T menyatakan bahwa "Saat terjadi kerusuhan, rombongan Mayjen Try Sutrisno, Jenderal Beni Moerdani, Letkol Inf. R.A. Butar Butar, Walikota dan lain-lain dating dengan menggunakan kendaraan jip yang dikemudikan sendiri oleh Mayjen Try Sutrisno. Duduk di sebelah kiri Mayjen Try Sutrisno adalah Jenderal Beni Moerdani, sementar di sebelah belakang duduk Dandim Jakarta Utara dan Walikota Jakarta Utara...“60 Laporan ini menunjukkan bahwa atasan-atasan tersebut berada di lapangan sehingga selain mereka mengetahui adanya kerusuhan atau kejahatan, mereka juga tidak melakukan perintah atau pengendalian apapun sehingga kerusuhan terjadi. Sehingga sejatinya telah memenuhi tiga elemen pertanggungjawaban komando yakni adanya hubungan atasan dan bawahan, adanya pengetahuan atasan terhadap kejahatan yang dilakukan oleh bawahannya (mens rea) dan adanya failure to act yaitu tindakan yang gagal diambil untuk mencegah, menghukum serta menghentikan tindak pidana yang dilakukan bawahannya (actus reus). ${ }^{61}$

\section{Kesimpulan}

Politik Hukum dan HAM yang terjadi pada awal era reformasi merupakan tanda adanya transisi dari suatu pemerintahan otoriter ke suatu sistem yang lebih demokratis. Tuntutan pemenuhan tersebut merupakan tujuan keadilan transisi dalam memenuhi hak-hak korban yang terlanggar karena terjadinya pelanggaran HAM berat masa lalu. Salah satu parameter yang dipakai dari empat jendela keadilan transisi adalah pemenuhan keadilan melalui penuntutan dengan cara memintai pertanggungjawaban pidana terhadap setiap orang yang bertanggung jawab. Salah satunya adalah dengan melalui pertanggungjawaban komando.

\footnotetext{
${ }^{59}$ Komisi Penyelidikan dan Pemeriksaan Pelanggaran Hak Asasi Manusia di Tanjung Priok (KP3T), "Ringkasan Eksekutif Hasil Penyelidikan,” http://jdih.komnasham.go.id/assets/uploads/ files/info_hukum/eksum\%20tanjung\%20priok.pdf diakses 31 Oktober 2020.

${ }^{60}$ Komisi Penyelidikan dan Pemeriksaan Pelanggaran Hak Asasi Manusia di Tanjung Priok (KP3T), ibid.

${ }^{61}$ P.L.T. Sihombing, Op.Cit.[70].
} 
Prinsip tersebut sudah berkembang dari saat pelaksanaan Konvensi The Hague 1907 sampai dengan terbentuknya International Criminal Court melalui Statuta Roma. Pada intinya, prinsip pertanggungjawaban komando terdiri atas hubungan atasan dan bawahan, pengetahuan atasan terhadap kejahatan yang dilakukan oleh bawahannya, dan adanya kegagalan dalam mengambil langkah untuk mencegah, menghukum, serta menghentikan tindak pidana yang dilakukan.

Permasalahan dalam peraturan nasional berkaitan dengan pertanggungjawaban komando sejatinya berawal dari penafsiran tidak utuh dan tidak jujur oleh Pasal 42 ayat (1) UU No.26 Tahun 2000 terhadap Pasal 28A Statuta Roma yang menjadi acuan dari Undang-Undang tersebut. Penafsiran tidak utuh dan tidak jujur tersebut berimplikasi pada konstruksi bahwasannya pertanggungjawaban komando adalah sesuatu hal yang fakultatif dan opsional, bukan wajib dan imperative serta komandan militer yang bertanggung jawab terhadap suatu pelanggaran HAM berat dapat diadili secara administratif maupun dalam peradilan militer, tidak perlu secara pidana. Hal ini diperkeruh oleh UU Peradilan Militer yang memuat rumusan subjektivitas kompetensi di mana untuk menentukan seseorang diadili di peradilan umum atau di peradilan militer ditentukan oleh musyawarah dan juga didasari oleh pertimbangan untung-rugi. Permasalahan lainnya adalah bahwa Indonesia mengacu pada Kitab Undang-Undang Hukum Acara Pidana yang diperuntukkan untuk pidana biasa (ordinary crime) untuk mengadili pelanggaran HAM berat yang notabene merupakan kejahatan luar biasa (extraordinary crime) sehingga dalam prosesnya kerap kali terhambat. Implikasi dari kelemahan-kelemahan tersebut dapat terlihat dalam kasus Tanjung Priok di mana nama-nama penting yang sudah sepatutnya bertanggung jawab tidak dimintai pertanggungjawabannya.

Prinsip hukum tentang tanggung jawab komando tentunya penting menjadi bagian dalam mewujudkan adanya pemenuhan penuntutan keadilan dalam menciptakan keadilan transisi. Tidak dijeratnya atasan atau komandan militer terhadap suatu peristiwa pelanggaran HAM berat tidak hanya menimbulkan ketidakadilan, tetapi juga melanggengkan impunitas. Hal ini berlawanan dengan tujuan terciptanya keadilan transisi yaitu untuk melawan impunitas. 


\section{Daftar Bacaan}

\section{Buku}

Atikah Nuraini, et. al., Hukum Pidana Internasional dan Perempuan (Komnas Perempuan 2006).

David Lanius, Strategic Indeterminacy in the Law (Oxford University Press 2019).

Eddy Djunaedi Karnasudirdja, Tanggung Jawab Seorang Atasan Terhadap Bawahan yang Melakukan Pelanggaran HAM Berat dan Penerapannya oleh Pengadilan Pidana Internasional dan Pengadilan Hak Azasi Manusia Indonesia (Tatanusa 2006).

Geoffrey Robertson, Kejahatan Terhadap Kemanusiaan: Perjuangan Untuk Mewujudkan Keadilan Global (Komnas HAM 2000).

ICTJ dan KontraS, Keluar Jalur Keadilan: Transisi di Indonesia Setelah Jatuhnya Soeharto (ICTJ dan KontraS 2011).

International Committee of The Red Cross, Commentary on the Additional Protocols to the Geneva Conventions (Martinus Nijhoff Publishers 1987).

KontraS, Menerobos Jalan Buntu: Kajian Terhadap Sistem Peradilan Militer di Indonesia (KontraS 2009).

KontraS, Reproduksi Ketidakadilan Masa Lalu: Catatan Perjalanan Membongkar Kejahatan HAM Tanjung Priok (KontraS 2008).

Muladi, Statuta Roma Tahun 1998 tentang Mahkamah Pidana Internasional Dalam Kerangka Hukum Pidana Internasional dan Implikasinya Terhadap Hukum Pidana Nasional (Alumni 2001).

Ruti G. Teitel, Keadilan Transisional Sebuah Tinjauan Komprehensif(ELSAM 2004).

Suparman Marzuki, Robohnya Keadilan: Politik Hukum HAM Era Reformasi. (PUSHAM UII 2011).

\section{Jurnal}

Abdul Hakim G Nusantara, 'Sebuah Upaya Memutus Impunitas: Tanggung Jawab Komando Dalam Pelanggaran Berat Hak Asasi Manusia’ (2004) 2 Jurnal HAM.

Gheanina Prisilia Kaban, 'Unsur-Unsur Tanggung Jawab Komando Di Dalam Hukum Pidan Internasional: Studi Putusan The Prosecutor V. Jean-Pierre 
Bemba Gombo/ICC-01/05-01/08' (2018) 1 Jurnal Ilmu Hukum Alethea.

Joko Setiyono, 'Penerapan Pertanggungjawaban Komando di Indonesia Atas Pelanggaran HAM Berat Kategori Kejahatan Terhadap Kemanusiaan’ (2010) 39 Masalah-Masalah Hukum.

P.L.T. Sihombing, 'Pertanggung Jawaban Komando' (2004) 2 Jurnal HAM.

\section{Laman}

Komisi Penyelidikan dan Pemeriksaan Pelanggaran Hak Asasi Manusia di Tanjung Priok (KP3T), 'Ringkasan Eksekutif Hasil Penyelidikan' (KP3T 2000) $<$ http://jdih.komnasham.go.id/assets/uploads/files/info_hukum/eksum\%20 tanjung\%20priok.pdf $>$ dikunjungi pada tanggal 31 Oktober 2020.

\section{Dokumen Internasional}

United Nations, Statute of the International Criminal Tribunal for the former Yugoslavia, Security Council resolution 827 (1993) 25 May 1993.

United Nations, Statute of the International Criminal Tribunal for Rwanda, Security Council Resolution 955 (1994) 8 November 1994.

United Nations, Rome Statute of the International Criminal Court, UNTS 2187 (1998).

\section{Perundang-undangan}

Indonesia. Undang-Undang Pengadilan Hak Asasi Manusia, UU No. 26 Tahun 2000, LN No.208 Tahun 2000.

Keputusan Presiden Republik Indonesia Nomor 129 Tahun 1998 Tentang Rencana Aksi Nasional Hak-Hak Asasi Manusia Indonesia.

\section{Putusan-putusan}

ICTR, The Prosecutor v. Jean-Paul Akayesu, ICTR-96-4-T, Trial Chamber 1, 2 September 1998.

ICTY, Prosecutor v. Kordic and Cerkez, Case No. IT-95-14/2-T Judgment (Feb. 26, 2001).

ICTY, The Prosecutor v. Zejnil Delalic, Hazim Delic, IT-96-21-T, 16 November 1998. 